\title{
VÍCTOR INFANTES DE MIGUEL, O LAS VENTURAS DEL LIBRO
}

\author{
VÍCTOR INFANTES DE MIGUEL, OR THE FORTUNES OF THE BOOK
}

Ignacio Gómez de Liaño

ABSTRACT: An outline of the personal relationship of an intellectual nature between the author and Víctor Infantes. It is structured as a convergence along four lines: the poetic experimentations of the author that began in 1964, and culminated in 1972 (experimental poetry); an interest in emblems and hieroglyphics; my book Juegos del Sacromonte; and finally, el conde de Villamediana, Don Juan de Tassis y Peralta, Correo Mayor de Felipe IV, Mercurio-Hermes de la Corte.

KEYWORDS: Víctor Infantes, Experimental Poetry, Emblematics, Juegos del Sacromonte, Juan de Tassis y Peralta.

RESUMEN: Un esquema de la relación personal de carácter intelectual del autor con Víctor Infantes. Se estructura como una convergencia en cuatro líneas: experimentaciones poéticas del autor, que se iniciaron en 1964 y culminaron en 1972 (poesía experimental); interés por los emblemas y jeroglíficos; los Juegos del Sacromonte; y en cuarto lugar, el conde de Villamediana, Don Juan de Tassis y Peralta, Correo Mayor de Felipe IV, Mercurio-Hermes de la Corte.

PALABRAS CLAVES: Víctor Infantes; poesía experimental; emblemática; Juegos del Sacromonte, Juan de Tassis y Peralta. 
Aquí tengo, delante de mí, dieciséis Pliegos del Crotalón, desde el primero, con Dos Poemas de Salvador López Becerra (octubre de 1983), hasta el décimo sexto, Tal vez salmos, de Rafael Gutiérrez-Colomer (enero de 1985). Entre el uno y el otro, veo pliegos con versos de viejos amigos, algunos ya desaparecidos y recordados con el mayor afecto -es el caso de Javier Utray, con el que viajé a Sicilia unos meses antes de su fallecimiento- como el propio editor, Víctor, al que quiero evocar de una forma más personal que académica en estas líneas. Los autores de otros pliegos están felizmente vivos, como Mario Hernández, al que conocí cuando tenía catorce años y ambos ya poetizábamos, o Luis Alberto de Cuenca, que en 1973 me sirvió de interlocutor cuando me puse a traducir del latín tratados mágicos y mnemónicos de Giordano Bruno, publicados ese mismo año por Taurus con el título de Mundo, magia, memoria.

Con el pliego número uno del Crotalón veo una nota escrita a mano, que dice:

$$
20-\mathrm{X}-83
$$

Querido Ignacio:

Allá te va mi primera "publicación» tipográfica;

ya hablaremos largo y tendido de ella.

Víctor

En 1983 ya había empezado nuestro coloquio o, para emplear sus palabras, nuestra complicidad. Complicidad a la que hace referencia en la dedicatoria quirográfica que encabeza su escrito La textura del poema: disposición gráfica y voluntad creadora (Separata), también de 1983:

Para Ignacio cómplice de éstos y otros muchos juegos. Víctor

Me he permitido transcribir estas palabras de amical erudición bibliográfica porque explican las razones que alimentaban nuestra complicidad. Cuando Víctor se puso en contacto conmigo, eran varias las líneas de convergencia. Sinteticémoslas:

La primera era mis experimentaciones poéticas, que se iniciaron en 1964 y culminaron en 1972. En esos años había hecho poesía visual (concreta, espacialista, semiótica), poesía de acción, poesía pública, exposiciones en importantes galerías (Juana Mordó, de Madrid), seminarios en el Instituto Alemán (Nuevas Tendencias) y otros centros. Y había organizado la parte de poesía experimental de los Encuentros de Pamplona de 1972, donde realicé poemas aéreos y otros poemas públicos. A esas actividades debo añadir mi manifiesto Abandonner l'écriture, que publiqué en Londres en febrero de 1969 en la revista OU - Cinquième Saison, que dirigía Henri Chopin. Su mismo título Abandonner l'écriture debió de ser un contundente aldabonazo en el espíritu de alguien como Víctor, para el que la escritura era el alma y razón de su existencia. Mas debo añadir que, desde la publicación de esa proclama en la que urgía a acabar con la escritura (a fin de extralimitarla, de llevarla más allá), ha pasado casi medio siglo y, en ese tiempo, no paramos... de escribir y leer, ni yo, ni el propio Víctor.

Ese era uno de los temas principales de nuestras primeras conversaciones. Me llamaba la atención que alguien con tan esmerada formación clásica de sabio universal del Renaci- 
miento, conociese tan a fondo los complicados entresijos de la historia de la poesía experimental española en la que me había movido tan intensamente desde que cumplí dieciocho años. De hecho, la primera historia de la poesía experimental en el mundo la estampé en el libro-catálogo de la exposición rotor - concordancia de artes, de 1967, y tres años después hice otro tanto sobre la poesía experimental española, en la revista alemana Akzente.

Pero nuestra complicidad iba más allá de la poesía experimental. Tenía otra línea de convergencia, que he insinuado unos renglones más arriba. Desde 1972, año en que me puse a estudiar a fondo las artes de la memoria de Giordano Bruno, me interesé de forma especial por los emblemas y jeroglíficos, desde Alciato, de cuyos emblemas tenía y, a Dios gracias, conservo una edición de comienzos del siglo XVI. De emblemas y jeroglíficos traté en varios escritos, sobre todo, en mi edición de De los heroicos furores, de Bruno, que publiqué en Alfaguara en 1987. Pues bien, la erudición de Víctor, en continuo proceso de combustión acumulativa, iba también por esos derroteros en los que el poema se daba la mano con la forma gráfica y la forma gráfica del poema con las artes del impresor, que Víctor cultivó a fondo por esas mismas fechas en la Imprenta Almeida.

No es casual que Víctor mencione, en "A modo de (in)necesaria justificación» de su Lyra mixta. Silva ejemplar de artificios gráfico-literarios, «la malograda edición de los Emblemas de Alciato en Editora, en el año 1975 [Madrid, Editora Nacional]», para la que yo había escrito un largo prólogo, que retiré por uno de esos enfados poco racionales a los que se es tan proclive de joven, y que unas líneas más abajo Víctor haga referencia a «los álgidos días de la poesía experimental española [...], el Instituto Alemán, los Encuentros de Pamplona», en cuyas actividades de tipo poético-experimental estuve implicado a fondo desde finales de 1966.

Este interés por los temas clásicos de la emblemática, los jeroglíficos, la magia (sobre todo, la de tipo mnemónico) que era nuestra segunda línea de convergencia y en la que Víctor ya destacaba por su singular erudición, una erudición que, por otro lado, acertaba a conciliar con el «experimentalismo» y, lo que es todavía más raro, con una ausencia total de presunción y ostentación, explica las palabras que puso al dedicarme La textura del poema. Allí se refiere a mí como "cómplice de éstos y otros muchos juegos». Esa palabra («juegos») saca a la luz un motivo esencial del inicio de nuestra relación. Hasta puede decirse que representa el resorte que impulsó a Víctor a establecer el contacto. El caso es que en el otoño de 1975 yo había publicado en Editora Nacional mi libro Los juegos del Sacromonte...

Ahí están los «juegos». Además, ese libro no se divide en Capítulos, sino en Estancias. Concretamente en doce, desde la primera, "Estancia del Laberinto», hasta la duodécima y última, "Estancia de la Risa». ¿Y qué había en ese libro que podía encandilar a Víctor? Varias cosas. Una, su carácter híbrido de historia, crítica literaria, filosofía, ficción. Otra, aún más importante, que la base de sustentación de mis Juegos era el hallazgo, a las afueras de Granada en tiempos de Felipe II, de una láminas ovaladas de plomo escritas en árabe con "caracteres salomónicos», que removieron literalmente Roma con Santiago y otorgaron al monte de Valparaíso el título de Sacromonte con el que se le conoce hasta ahora. A causa de esos hallazgos, se erigió una impresionante abadía, se formaron cortejos procesionales, se produjeron milagros.

Los libros de plomo de Granada planteaban la cuestión de la verdad que hay en las ficciones y la ficción que hay en las verdades. Y, sobre todo, evidenciaban cómo el conocimiento de esa singular historia de sagrados libros apócrifos indujo a Don Miguel de Cervantes a forjar la personalidad de su héroe, al que yo dediqué la «Estancia del Caballero de los Libros», una personalidad en la que la ficción de los libros de caballerías se hace realidad y vida; y le indujo a armar la singular forma meta-literaria de la novela, sobre la base de la 
arábiga crónica de Cide Hamete Benengeli con la correspondiente apócrifa traducción. Don Miguel alude a los hallazgos granadinos en la última página de la Primera Parte del Quijote, que Víctor Infantes (no en vano 'de Miguel') conoce como nadie, según ha demostrado en La primera salida de El ingenioso hidalgo don Quijote de la Mancha (Madrid, Juan de la Cuesta, 1605). La historia editorial de un libro, singular investigación de la que Víctor ha sido editor, además de coautor.

La cuarta y definitiva línea de complicidad vino de la mano de un coetáneo de Cervantes, de un amigo de Góngora, del Correo Mayor de Felipe IV, del Mercurio-Hermes de la Corte. O sea, del conde de Villamediana, Don Juan de Tassis y Peralta. Un día me trajo a casa Víctor una fotocopia de La fábula de Criselio y Cleón, de Diego Ximénez de Enciso. Esa obra, inédita entonces, la mandó escribir el Conde-Duque de Olivares, gran rival de Villamediana, para «justificar» el vil asesinato de éste el 21 de agosto de 1622 en la calle Mayor de Madrid, que tanta conmoción produjo, como se ve en una famosa carta de don Luis de Góngora. La fotocopia que me traía Víctor correspondía a uno de los dos únicos manuscritos que se han conservado, concretamente el de la Biblioteca Pública de Toledo. El interés de esa versión reside en que al hacer la lista de los personajes de la Fábula, el copista pone las iniciales de las personalidades reales en que el autor se basaba:

$\begin{array}{ll}\text { Iupiter } & \text { El R. Ph. III } \\ \text { Criselio } & \text { El R. Ph. IV } \\ \text { Cleón } & \text { El C.D. } \\ \text { Alcino } & \text { El C.D.VM. } \\ \text { Amphiloco } & \text { D.B.D.Z. } \\ \text { Nerea } & \text { D.F.D.T. }\end{array}$

Como había dedicado varios años al estudio de Villamediana, sobre el cual tenía en casa una pequeña biblioteca, fue cosa fácil descifrar esas iniciales. Y así, en los personajes que acabo de enumerar, que son los principales de la obra, vimos aflorar las fisonomías de Felipe III, Felipe IV, el Conde-Duque, el Conde de Villamediana, Don Baltasar de Zúñiga, Doña Francisca de Tabora (o Tavara). Y, ni cortos ni perezosos, nos pusimos a escribir un estudio sobre la extraordinaria aportación que esa obra de teatro hacía para iluminar las razones del oscuro asesinato del gran conde de Villamediana. Ese escrito y la edición crítica de la Fábula de Criselio y Cleón se publicaron en El Crotalón. Anuario de Filología Española 1 (Madrid, 1984) y, posteriormente, en mi libro misceláneo Paisajes del placer y de la culpa (Madrid, Tecnos, 1990).

De los encuentros que tuve esos años con Víctor Infantes se destaca en mi memoria el viaje que hicimos, conducidos por él, Luis Alberto de Cuenca y yo a Torrelavega (Cantabria), donde leímos algunos poemas y de donde resultó un cuaderno dual, que comprende La caza de Acteón y Breviora, poemas realizados por el que esto firma el primero, y por L. A. de Cuenca el segundo. Ese cuaderno se publicó en Torrelavega en 1984 bajo los auspicios de Rafael Gutiérrez-Colomer, al que Víctor dedicó uno de sus Pliegos del Crotalón y al que conocí en aquella tan memorable ocasión.

Como en 1985-1986 residí en Japón y en 1989-1990, en Pekín, nuestra relación tuvo sus interrupciones, pero aunque en los últimos años nos vimos poco, siempre tenía presente en mi memoria la imagen de Víctor y la trayectoria de su magisterio. Otros, más cualificados que, yo tratarán de esa trayectoria, en la que Víctor ocupa una estancia destacada junto a las que ocupan personalidades tan relevantes como Marcelino Menéndez y Pelayo o Antonio Rodríguez-Moñino. En el magisterio de Víctor Infantes la erudición filológica e historiográfico-literaria se daba la mano con una grata sencillez y naturalidad, con un saber estar dondequiera que fuese. Y, sobre todo, con una singular pasión por el saber y los libros. 
Los libros, he dicho. Cuando ahora repaso La primera salida de El ingenioso hidalgo don Quijote de la Mancha (Madrid, Juan de la Cuesta, 1605). La historia editorial de un libro, y veo hasta qué punto él y Ana Martínez Pereira se comprometieron en la aventura de ver, de tener en las manos, de analizar, de hacer el censo de todos y cada uno de los veintiséis ejemplares que han llegado hasta nuestro tiempo de la primera edición del Quijote, me vino a la mente esta idea peregrina: Si yo, en 1975, llamé a Don Quijote de la Mancha el Caballero de los Libros, ahora, a la altura de 2013, que es cuando salió a la calle La primera salida..., debía dar a Víctor Infantes de Miguel ese título, u otro semejante, como el de Caballero del Quijote o el de Quijote de los Libros. Hasta tal punto, ha encarnado Víctor la aventura de los libros y la literatura, de la imprenta y las artes gráficas, de los jeroglíficos y, sobre todo, de la amistad.

Curiosamente, me he puesto a escribir estas líneas al día siguiente de dar una conferencia en la Alhóndiga de Villanueva de los Infantes. Allí he visitado la Casa del Caballero del Verde Gabán, con su penumbroso patio central. Su actual propietario tuvo la deferencia de abrirla para mí. En Villanueva de los Infantes se siente por todas partes la libresca sombra de Don Quijote de la Mancha y, obviamente, la de alguien como Víctor cuyo primer apellido es, justamente, Infantes, y el segundo, de Miguel. Y visité también la tumba de Quevedo y la celda del convento de los dominicos donde este gran rival de Cervantes exhaló su postrer aliento y escribió su último soneto y cartas llenas de emoción.

Ahora, al abrir el librito De la Imprenta, que publicó Víctor en 1997, cuando después de leer su dedicatoria "Con un abrazo impreso. Víctor», he posado la mirada en la primera frase del segundo de los escritos que lo componen, «El espacio gráfico y literario del libro (La memoria es un silencio de madera)", me he venido a topar con la clave de la gran pasión de Víctor en esta frase inicial:

El libro ha sido, y quizás es todavía, el ídolo portátil de nuestra historia cultural. Tótem multiplicado en sí mismo, repetido y variable (siendo siempre el mismo) y portador del virus del conocimiento (y de la vacuna contra el mismo virus).

Si a alguien se le ocurriese fundar, o más bien refundar, la Religión del Libro, debería saber que esa religión tuvo un Precursor, que ese Precursor se llamaba Víctor y que el Génesis que da principio a la Nueva Biblia se titula El ingenioso hidalgo don Quijote de la Mancha. 
